\title{
Correction: The Role of a7 Nicotinic Acetylcholine Receptor in Modulation of Heart Rate Dynamics in Endotoxemic Rats
}

\author{
Roham Mazloom, Golnar Eftekhari, Maryam Rahimi-Balaei, Vahid Khori, \\ Sohrab Hajizadeh, Ahmad R. Dehpour, Ali R. Mani
}

The third author's name is incorrect. The correct name is: Maryam Rahimi-Balaei. The correct citation is: Mazloom R, Eftekhari G, Rahimi-Balaei M, Khori V, Hajizadeh S, Dehpour AR, et al. (2013) The Role of $\alpha 7$ Nicotinic Acetylcholine Receptor in Modulation of Heart Rate Dynamics in Endotoxemic Rats. PLoS ONE 8(12): e82251. doi:10.1371/journal.pone.0082251

\section{Reference}

1. Mazloom R, Eftekhari G, Rahimi M, Khori V, Hajizadeh S, Dehpour AR, et al. (2013) The Role of $\alpha 7$ Nicotinic Acetylcholine Receptor in Modulation of Heart Rate Dynamics in Endotoxemic Rats. PLoS ONE 8(12): e82251. doi: 10.1371/journal.pone.0082251 PMID: 24340009

fopenaccess

Citation: Mazloom R, Eftekhari G, Rahimi-Balaei M, Khori V, Hajizadeh S, Dehpour AR, et al. (2015) Correction: The Role of a7 Nicotinic Acetylcholine Receptor in Modulation of Heart Rate Dynamics in Endotoxemic Rats. PLoS ONE 10(5): e0127826. doi:10.1371/journal.pone.0127826

Published: May 1, 2015

Copyright: @ 2015 Mazloom et al. This is an open access article distributed under the terms of the Creative Commons Attribution License, which permits unrestricted use, distribution, and reproduction in any medium, provided the original author and source are credited. 